\title{
Optanternes Retssilling.
}

Af P. Skovrøy.

I en hel Menneskealder har dette Forhold ventet paa sin endelige Ordning, et klart og utvetydigt Retsgrundlag, der hverken giver Rum for spidsfindige Fortolkninger eller for politiske Eksperimenter af den Art, som vi nu er Vidne til, da de danske Undersaatter bruges som „Kanonføde“ og som politiske "Stormbukke“ i Fortyskningskampen mod den danske Befolkning i Slesvig.

Det er ikke Meningen her at drøtte de egentlige danske Udlændinges Retsstilling, som udelukkende er begrundet i de almindelige Folkeretsregler.

Det er kun de saakaidte Optanters Retsstilling, der har en positiv Hjenmel, dels i Wien-Fredens Art. 19, dels i Aabenraakonventionen, som her skal behandles.

Disse Optanter maa inddeles $i$ to Klasser:

1) Optanterne fra 6 Aars Fristen fra 1864 til 18\%0,

2) Optanterne og andre Personer, som nyde Opholdsret i Henhold til Aabenrakonventionen af 1872 .

Den forste Klasses Retsstilling er begrundet ved Wien-Freden Art. 19, der lyder saadan:

„De Undersaatter, der er bosatte i de ved denne 
Truktat afstaaede Landsdele, nyder $i$ et Tidsrum af seks Aar, at regne fra den Dag Udrekslingen af Ratifikationerne har fundet Sted, efter en foregaaende Erklæring til den kompetente Myndighed, den fulde Ret til at udføre deres Bohave tolufrit og gaa med deres Familie til Danmark med Anerkjendelsen af Ret som danske Undersaatter. Det tilstaaes denı at beholde urørligt Gods i de afstaaede Landsdele.

Samme Ret tilstaaes paa den anden Side danske Undersaatter og saadanne $\mathrm{i}$ de afstaaede Landsdele, der er bosiddende i Danmark.

Undersaatter, der kommer til at nyde godt af disse Dispositioner, maa ikke paa Grund af deres Option kunne forulempes, hverken paa Person eller Ejendom i de respektive Stater.

Den næunte Frist af seks Aar fincler ogsaa Anvendelse paa de oprindelige Undersaatter baade $i$ Danmark og de afstaaede Landsdele, der paa Tidspunktet for Udvekslingen af rærværende Traktats Ratifikationer befinder sig uden for Danmarks eller Hertugdønmernes Omraade. Deres Erklæring kan modtages af det nærmeste danske Gesandtskab eller den overste Provinsmyndighed, saavel i Danmark som i Hertugdømmerne.

Den der paa Tidspunktet for Udvekslingen af nærværende 'Traktats Ratifikation har Indfødsret, beholder samme."

Skønt denne Fredsartikel har det tilfælles med saa mange Traktatbestemmelser, at den er sjusket affattet, saa fremgaar Opholdsretten for de danske Optanter dog utvivlsomt ved en nærmere Betragtning. 
Det farste Punktum, som kun indeholder en Bestemmelse om Toldfriheden og om Undersaatternes $R$ et til at forlade Landet, tager aabenbart Sigte paa de mange danske Enbedsmænd, som maatte antages at ville forlade det erubrede Land og gaa tilbage til Kongeriget. Men denne Bestemmelse blev straks af de projsiske Myndigheder misforstatet som indeholdende en Pligt for de Opterende til at forlade Landet. Man oversaa her, at ved en slig Fortolkning, vilde den folgencle Bestemmelse om, at ,Optanterne ikke pa $\dot{0}$ ruud af deres 0 ption maatte forulempes paa Personen" blive fuldstændig meningslus; thi naar Optanterne ikke turde blive boende i slesvir, men matte forsvinde over Grænsen straks ved Optionen, saa kunde der jo ikke godt blive Tale om, at deres Person kunde blive forulempet.

I Virkeligherlen er disse Optanters Retsstilling i Kralt af deme Artikel fuldkommen lig med de projisiske Undewaatters i Henseende til den personlige Lkr ienkeligh hed. Der siges jo nemlig udrykkelig, at deres Person ikke maa forulempes pa a Grund af optionen. Det vil altsaa ogsaa sige, at disse Optanter ikke kunne blive udviste som de egentlige Udlaundige, thi en Landsforvisning er dog sandelig en personlig Forulempelse, hvis noget her i Verden kan kaldes saadan.

Opholdsretten er sitaledes utvivlsomt hjemlet $\mathrm{ud}$ trykkelig i Artiklen; men dernxst fremgaar den med Norlvendighed at Forholdenes Natur og „Lovgrunden“. Thi hvorfor blev Artiklen overhovedet optaget i Traktaten? For at lette de danske slesvigere Overgangen til et andlet Statsiamfund, men sandelig ikke for at jage dem wd af Laniet. Ingen af Parterne tilsigtede en Af- 
folkning af Noriklesvig, men søgte tværtimod at forhindre Udvandringen til Danmark derved, at man optog Art. 19 i Traktaten, som tillod Undersaatterne at hlive boende i Landet som danske. Man vilde skaane den da levende Generations Følelser. Man var jo ikke blind for, at den Del af den erobrede Befolkning i Slesvic som var dansksindet, ikke saa med velvillige Øjne paa Erobreren, samt at alle de, der kort forinden havde baaret Valben imod Prøjserne og forsvaret deres Fædreland, mantte gyse tilbage ved Tanken om, maaske inden kort Tirl at kunne blive trungen til at staa $i$ Kampen overfor deres exne Brødre og Landsmænd, eller at deres Sxnner kunde komme i denne Stillingr. Det var altsaa af Hensyn til den danske Befolknings berettigede Folelser ou for at forebygge en Udvandring $i$ stor Stil at Artikel 19 blev optaget. Dette vil ingen nægte. Men hvis Artikel 19 ikke hjemler Optanterne en Ret til at blive boende $\mathrm{i}$ Slesvig, og hvis man hævder, som man paa projsisk Side har gjort, at en Udvandring er betinget i Optionens Natur, saa blev jo de danske Optanters Retsstilling paa Grund af Artikel 19 ringere end Udlændinges, og Masseudvandringren, som man vilde forebygge ved Artikel 19 maatte hlive fremkaldt ved denne Bestemmelse, hvad den jo faktisk blev, takket rare de projsiske Myndigherlers Misforstaaelker og Misgreb. Derfor er den proj̣iske Opfattelse af Artikel 19 i Wien-Freden uforeneligr med sund Fornutt.

I hvor hoj Grad defte sidste er Tilfieldet bevises mest shande derved, at man fra projsisk side ved tidligere Forhandlinger har gijort hele tre forskellige Opfattelser af Optanterues Retsitilling galdende: 
1) hævdede den prøjsiske Indenrigsminister Puttkamer paa Hans Lassens Forespørgsel den 7. Marts 1883 i Landdagen, at Artikel $19 \mathrm{i}$ Wien-Freden indeholdt den Bestemmelse, at de opterende matte udvandre til Danmark.

I Følge denne Opfattelse er Optanternes Retsstilling ringere end de sædvanlige Udlændinges.

2) hævdede den prøjsiske Minister gennen den tyske Gesandt i København den 20. Febr. 1883: „Hvad angaar de i Nordslesvig anordnede Forholdsreglers formentlige Strid med sluttede Overenskomster, saa have Overenskomsterne med Danmark i hvert Fald ikke indrømmet de slesvigske Optanter flere Rettigheder, end der tilkommer enhver anden Udlænding, og disse Optanter kunne derfor, lige som enhver anden Udlænding, til enhver Tid udvises."

I Følge denne Opfattelse er Optanternes Retsstilling ikke ringere men fuldkommen lige med Udlændinges.

3) hævdede forleden Regeringspræsident Köller overfor ,Politiken"s Medarbejder, at Optanter ikke kunde udvises, dersom de ikke havde forbrudt sig imod Lovene.

I Følge denne Opfattelse er Optanternes Retsstilling ikke ringere eller lig med Udlændinges, men bedre, for saa vidt som, efter Köllers Mening, en Optant ikke kan udvises, forinden han har forset sig imod Lovene. Hr. Köller staar aabenbart med sin Opfattelse paa Aabenraakonventionens Grund.

Ingen af disse tre forskellige Opfattelser er imidlertid den rette. Hr. Köllers Opfattelse er - skønt han er den, der i Praksis har været mest gram over for de 
danske Lndersaatter - den mest rimelige; men han begaar den Fejl at anvende Aabenraakonventionen paa Optanterne fra 6 Aars Fristen, hvis Retsstilling har selvstændig, positiv Hjemmel i Wien-Fredens Artikel 19.

Disse Optanter's Opholdsret er jo i Medfør af denne Traktatbestemmelse ubetinget, medens Opholdsretten efter Aabenraakonventionen er betinget, næmlig af, at de paagældende ikke give Anledning til begrundede Klager, eller lægge et fjendtlig Sindelag mod den prøjsiske Stat og dens Undersaatter for Dagen.

Den sidste Bestemmelse aabner en vid Mark for Fortolkninger, medens Bestemmelsen i Artikel 19 i WienFreden nat Optanten ikke paa Grund af Optionen maa forulempes paa Person eller Gods" er klar og uanfægtelig.

At Optanterne fia 6 Aars Fristen staa uberørte af Aabenrakkonventionen fremgaar alene deraf, at en Kommission som den, der blev nedsat i Aabenraa i 1871, ordentligvis ikke kan ophæve Wien-Traktatens Bestemmelser, allermindst kan en slig hommission formindske de ved en Fredstraktat hjemlede Rettigheder.

Men det samme fremgar desuden af Forholdenes Udvikling og selve Aabenraakonventionens Ordlyd.

Optantsagens Udvikling kom straks ind paa vildsomme Veje og endte tilsidst i det skrbnesvangre Ufore, hvor den endnu sidiler fast. De projsiske Myndigheder tog fra forste Færd med haard Haand paa denne Sag, i det man befalede de opterende, for saa vidt de vare $i$ den militærpligtige Alder og stundom ogsaa uden, at være ude af Landet inden 14 Dage. Nogrle projsiske Herredsfogder forelagde endog de Folk, som onskede at optere, til Cnderskrift en Forplintelse til at være ude af Landet 
inden en vis Frist, medens atter andre Myndigheder ikke knyttede denne Betingelse til Optionen, lige som det ogssa hændte, at en opterende nægtede at underskrive en slig Erklæring og dog blev udskrevet.

Det er en Selvfølge, at denne Misforstarelse af Traktatens Bestemmelse, i Forbindelse med denne Famlen i Opfattelsen og Mangel paa Ensartethed i Udførelsen maatte afføde Usikkerhed i Befolkningen, som følte sin Ret krænket, men maatte bøje sig for Magten. Og da i 1870 den prøjsiske Hær mobiliseredes mod Frankrig i Marts Maaned, endnu inden 6 Aars Fristen efter WienFreden var udløben (den udløb 16. Nov. 1870), og Indkaldelserne $\log$ ned $i$ de slesvigske Landwbyer, var Opskræmtheden og Usikkerhedsfylelsen sul stor, at det slog ud i en tojlesløs Forvirring. Paa Grund af Unrden i de prøjsiske Lægdsruller hændte det endogsaa, at danske Optanter fik Indkaldelsesordre. Dette satte Kronen paa Værket. Gamle Soldater, der for seks Aar siden havde kæmpet imod Prøjserne ved Dybbøl, gyste tilbage for den Tanke, at de ved en Indkaldelse kunde komme til at staa med Bajonetten i Haanden overfor deres danske Kammerater fra Dybbøl, over for Venner og Frænder, ja Brødre, Fæilre eller Sønner, som havde opteret for Danmark. Det var jo næmlig en almindelig Mening, at Danmark vilde deltage $\mathrm{i}$ Krigen. Mange Optanter tro. de, at deres Option ikke respekteredes, og haade Optanterne or unge Folk, som stode for Indkaldelsen og endnu vilde benytte 6 Aars Fristen til en Option, samt Folk, der allerede havde modtaget Indkaldelsen, flygtede i Hobetal over den danske Grænse.

Efter at den fransk-tyske Krig var endt, begyndte 
disse Personer efterhaanden at søge tilbage til den hjemlige Arne. $\mathrm{Og}$ nu tog Udvisningen Fart. Man udviste uden tilsyneladende at gøre mindste Forskel paa, om de udviste vare Optanter eller ej. Man slog ned paa dem, hvor man fandt dem. Det var som den vilde Jagt, som under den kullede Greve, da „Dansken var tredløs i Skov og paa Hede", og ondsindede Hjemmetyskere agerede Støvere i Ledtog med tyske Smaablade, som hujede og bjæffede af Skadefiryd under denne Menneskejagt.

Omsider blev det for broget for begge Parter. For om muligt at komme til en Forstaaelse, blev der i 1871 nedsat en international Kommission til Sagens Ordning, i hvilken deltog paa dansk Side: Kongelig Kammerherre og Stiftamtmand i Aalborg, Fredrik v. Dahlstrøm og Kongelig Oberst og Kommandant paa Bornholm, Eduard v. Fallesen, og paa tysk Side: den kongelig prøjsiske Generalmajor og Kommandør for 15. Brigade, Heinrich v. Blumenthal af Flensborg og Kongelig prøjsisk GeheimeRegeringsraad og Landraad for Flensborg Kreds, Vilhelm Krupka.

Denne Kommission undertegnede den 16. Januar 1872 en Slutningsprotokol, den saakaldte Aabenraakonvention, angaaende Behandlingen af de til Danmark udvandrede slesvigske og holstenske værneplig tige.

Kommissionen betegner straks i Begyndelsen sin Opgave som den: at prøve de værnepligtige og Reservisters Forhold, som i Sommeren 1870 tog til Danmark.

Kommissionen har lavet en Fortegnelse over alle disse Personer og inddelt dem i 3 Lister A, B og C.

I Liste $\mathrm{A}$ indeholdes de Personer, som have opteret 
for Danmark indenfor den i Wien-Fredens Artikel 19 foreskrevne 6 Aars Frist, altsaa de egentlige Optanter.

Denne Liste bliver af Kommissionen behandlet meget sunımarisk med følgende Ord:

"Samtlige i Liste A opførte Mandskaber blive utvivlsomt at anerkende som danske, og der vil uden Betænkelighed kunne tilstedes dem varigt Ophold i Slesvig, efter at det er godtgjort, at de ved Indkaldelsen allerede vare at betragte som danske $\mathrm{og}$ derfor ikke have forbrult sig mod de prøjsiske Straffelove."

Der ligger i disse Ord en aaben Anerkendelse af Optanternes Ret til at opholde sig her i Slesvig. Der sires jo udtrykkeligt, at der ingen Betænkelighed kan være ved at tilstede Optanterne varigt Ophold i Slesvig, fordi de ikke have forbrudt noget. Det vil med andre Ord sige, at Kommissionens Behandling ikke vedrører disse I'ersoner, at Aabenraakonventionen ikke finder Anvendelse paa dem, at deres Retsstilling ma bedommes uafhængig af Traktaten af 1872.

En anden Fortolkning er umulig. ' Thi sat, at disse Optanter i 1870 alle tilhobe vare forblevne i Slesvig og Holsten, saa vare de ikke blevne optagne i Kommissionens Lister og altsaa heller ikke blevne næunte i Aabenrakonventionen, og deres Retsstilling kunde da ordentligvis ikke anses som berørt af en Traktat, der slet ikke nævner dem. Men lige saa lidt kan deres Retsstilling blive berørt derved, at de af Frygt for en uberettiget Indkaldelse udvandre oor senere blive behandlede $\mathrm{i}$ en Overenskomst sammen med andre Personer, hvis Retsstilling er af en ganske anden og ringere Art. Dette vilde jo være det 
samme som at gøre det tyske Mundheld: „Mit gefangen, mit gehangen!“ til en alvorlig Retsgrundsætning.

Men det er heller ikke Aabenraakonventionens Mening, at Optanter fra 6 Aars Fristen skulle indbefattes under den. For alle de Optanters Vedkommende, som vare udvandrede eller udviste før 1870 og slet ikke ere medopforte paa Kommissionens Lister er dette jo klart, thi Overenskomsten siger udtrykkelig $\mathrm{i}$ sin Indledning, at den behandler de værnepligtiges Forhold, som i Sommeren 1870 flygtede til Danmark, og i de to Noter, som udveksles mellem de to Regeringer den 25. Septbr. $1872 \mathrm{i}$ Anledning af Traktatens Ratifikation, hedder det endvidere „væruepligtige, som paa Grund af den projsiske Armees Mobilisering i 1870 gik til Dammark."

Desuilen taler Aabenrakonventionen liele Tiden uilelukkende om „værnepligtige“; men til den Kategrori høre Optanterne ikke - de vare jo netop ikke vær nepligtige, siger Traktaten selv, fordi de vare danske Optanter.

Af foranstaaende fremgaar formentlig, at de Optanter, som have opteret i Seksaarsfristen i Henhold til Artikel 19 i Wien-Freden, nyde en ubetinget Ret til ophold i Slesvig og lige saa lidt kunne udvises som de prøjsiske Statsborgere.

Og nu med Hensyn til 2. Klasse af Optanter og andre Personer, som lave Opholdsret i Henhold til Aabenraakonventionen. Det er i Følge denne Traktats Liste B og C dels Optanter, som først have opteret efter Modtagelsen af Indkaldelsesordren i 1870 , men inden 6 Aars Fristens Udløb (6. November), dels saadanne, som 
have opteret efter Fristens Udløb og unddraget sig den projsiske Militairtjeneste ved at gaa til Danmark i 1870 .

Disse Personers Retsstilling er ringere, for saa vidt som deres Opholdsret er betinget af, at de ikke give Anledning til begrundede Klager og ikke lagge fjendtligt Sindelag mod den prøjsiske Stat eller dens Undersaatter for Dagen.

Endnu staar tilbage at undersøge et Spørgsmaal af overordentlig Rækkevidde, næmlig

\section{Optantbørnenes Forhold og Retsstilling.}

Medens i Følge den danske Indłødsretslov alle Personer erhrerve dansk Indfødsret ved Fødselen, er dette ikke Tilfældet i Prøjsen efter den tyske Indfødsretslov af 1. Juni 1870 idet kun Born af tyske Undersaatter erhverve Indfødsret i Tyskland; Børn af Udlændinge ere og forblive Udlæendinge lige som Faderen.

Som Følge heraf ere alle Bør'n af de danske Optanter i Slesvig danske Undersaatter efter prøjsisk Begreb.

Syørges der nu om disse Borns Retsstilling, saa maa det hævdes at Børn, der var fodte den 16. Nov. 1864 (den Dag Wien-Fredstraktaten ratificeredes) maa nyde samme Ret som Faderen, der har opteret inden 6 Aars Fristens Udløb, for saa vidt Børnene ikke vare myndige, da Faderen opterede.

I Samklang hermed staar oysaa en Erklaring, som det danske Udenrigsministerium under 29. Maj 1879 har tilstillet en dansk Undersaat her i Slesvig som Svar paa en Forespørgsel. I denne Skrivelse hedder det:

„De i længere Tid mellem den kgl. danske og ligl pryjsiske Regering forte Forhandlinger om den 
statsretlige Stilling, son tilkommer Børnene af de $i$ Slesvig boende danske Undersaatter, har ført til det Resultat, at den prøjsiske Regering anerkender, at Børn af Forælire, som i Følge Artikel 19 i Fredstraktaten af 30. Oktober 1864 have afgivet den Erklæring, at de ville vedblive at være danske Undersaatter, maa anses for at have bevaret deres danske Nationalitet, naar de vare umyndige og undergivne den fi.lerlige Myndighed paa den Tid, Erklæringen blev afgiven, saafremt der ikke udtrykkelig ved denne Erklæring er gjort et modsat Forbehold. Som Falge af Ovenstaaencle er fra prøjsisk Side oysaa Deres Søn anerkendt som dansk Undersaat og i denne Egenskab befriet for den prøjsiske Militærtjeneste." Som man ser gaar denne Erklæring lidt videre, i det den hævder, at alle Børn, som ere fødte $\mathrm{f} ø \mathrm{r}$ Faderens Option inden for 6 Aars Fristen, ere danske Undersaatter, eller rettere sagt af den prøjsiske Regering anses for at have bevaret deres danske Nationalitet, thi danske Undersaatter er efter dansk Statsret kun de Børn der ere føite før 6. Nov. 1864. I Følge prøjsisk Statsret staa Optanters Børn endog i uendelige Led uden for det projsiske Statsborgerforhold, med mindre de have ladet sig naturalisere eller for Kvindernes Vedkommende have indgaaet \#gteskab med prøjsiske Statsborgere.

Man vil forstaa, at der under disse Forhold leve flere Tusinder af vore Landsmænd her i Slesvig, hvis statsretslige Stilling svæver mellem Himmel og Jord, i det de efter prøjsisk Opfattelse er danske Undersaatter, men efter dansk Lov ikke er det. Sæt at disse Personer blive udviste af Prøjsen, og sæt at Danmark ikke er 
godmodigt nok til at modtage dem, hvad saa? Thi Danmark er kun forsørgelsespligtig overfor sine egne Undersaatter.

Heri er der ikke indtraadt nogen Forandring ved den under 19. Marts 1898 udstædte danske Lov om Erhvervelse og Fortabelse af Indfødsret, eftersom Lovens sidste § udtrykkelig fremhæver, at Loven ikke angaar de Personer, hvis Indfødsret er forbeholdt i Henhold til Wien Fredstraktatens Art. 19.

Imidlertid har det dog $\mathbf{i}$ adskillige Tilfælde, hvor Optanternes Hjemstedskommune har nægtet at modtage Optanternes Børn, vist sig, at Prøjsen har maattet bekvemme sig til at overtage Forsørgelsen af disse trængende Personer, naar de vare fødte her i Slesvig.

Prøjsen har vel tidligere forsøgt sig paa at løse denne Knude, men rigtignok ved paa ægte Militærstatsvis at hugge den over med Sværdet.

Det udtales i Aabenraakonventionen, at dette anomale Forhold for Fremtiden skulde skaffes af Vejen og event. ad Lovgivningsvejen drages Omsorg for, at de kommende Generationer af denne Befolkning ved deres Fadsel i Prøjsen bleve Prøjsere.

Dette billigedes af de danske Kommissærer, og den danske Regering udstædte Loven af 4. April 1873, som fritager tyske Undersaatter i Danmark for Militærtjeneste.

Det hedder i Aabenraakonventionen, at Sagen skal ordnes for de kommende Generationer som fødes. Dermed er udelukket de Generationer, som er fødte før den 25. Sept. 1872 (Aabenraakonventionens Ratifikationsdatum). Endvidere siges der, at Ordningen skal ske ved $\mathrm{L} 0 \mathrm{v}$.

Desuagtet udstædte den prøjsiske Regering den 
7. Januar 1883 en Kundgørelse, der truede alle danske Undersaatter, som i dette Aar fyldte deres tyvende Aar, med Udvisning, dersom de ikke meldte sig til prøjsisk Militærtjeneste og Naturalisation.

Denne Kundgørelse udstædes endnu hvert Aar, til Trods for at den strider imod alle mulige Love og Traktater. Den strider imod Wien-Fredens Artikel 19, den strider imod Aabenraakonventionen; thi for det første er det ingen Lov, som denne bebuder, men en simpel administrativ Forholdsregel, for det andet kommer den mindst 10 Aar for tidlig (jæunfør „kommende Generationer" i Traktaten) og for det tredje kræver Traktaten som Grund for Udvisning „begrundede Klager“; men man kan da virkelig ikke sige om en Yngling, at han giver Anledning til begrundede Klager ved at han - træder ind i sit tyvende Aur! Den strider endvidere imod den tyske Militærlov af 9 . November 1867 og den tyske Rigsforfatnings Art. 57, som forudsætte, at Hæren bestaar af Tyskere, og den strider mod al tysk Lovgivning, som ikke noget Steds omtaler Udlændinges Værnepligt.

Jeg gad vide, hvorlunde de tyske Retsiærde vilde forsvare denne Forvaltningsforholdsregel over for de internationale Overenskomster og Prøjsernes egne Love. Man kan ikke engang hævde, at man først gør de unge Folk til prøjsiske Statsborgere og derpaa tager dem til Soldat, eftersom det er hændt, at de først blive naturaliserede efter at de have tjent som projsisk Soldat.

I Medfør af hvad der i det foreganende er udviklet, or man formentlig kunne fastslaa følgende: 


\section{Optanter og deres Børn.}

1) De Optanter, som have opteret i 6 Aars Fristen fra 16. Nov. 1864 til 16 Nov. 1870 kunne ikke udvises.

Samme Ret tilkommer ubetinget dem af deres Børn, som ere fødte den 16 . Nov. 1864 , samt i Følge en Exklæring af den tyske Regering i 1879 ogsaa dem, der vare fødte, da Faderen afgav sin Erklæring og som paa den Tid endnu vare mindrea arige. For Eksempel, naar Faderen først har opteret den 15. Nov. 1870 nyder hans dafødte Børn samme Ret som han, for saa vidt de vare mindreaarige den 15 . November.

2) Optanter, hvis Retsstilling maa bedømmes efter Aabenraakonventionen. Det vil sige Folk, som have opteret dels før 16. Nov. 1870, men som paa Grund af deres Forhold ere blevne behandlede i denne Overenskomst, dels formentlig de, som have opteret efter 1870 men før Aabenraakonventionen, dels endelig Folk, som ikke have opteret, men som ved denne Konvention have faaet Opholdsret i Slesvig i "Egenskab af danske Optanter“.

Disse Folk kunne kun udvises paa begrundede Klager.

For at en Klage kan siges at være begrundet, maa det ordentligvis kræves, at den anklagede er bleven hørt og har faaet Adgang til at kuldkaste ubevislige Sigtelser.

I Henseende til disse Folks Børn, er det tvivlsomt, hvor vidt disse kunne gøre Krav paa samme Retsstilling som Faderen. For de Børns Vedkommende, som er fødte 
før Aabenraakonventionen turde det være Tilfældet, jævnfør Udtrykket i Konventionen „de kommende Generationer“.

3) Folk der have opteret for Danmark efter Aabenraakonventionen og disses Børn kunne kun kræve at blive behandlede som Udlændinge efter folkeretlige Vedtægter mellem suveræne Stater, og at denne Ret $\mathrm{i}$ vore Dage er afhængig af $\mathrm{Hr}$. Køllers $\mathrm{N}$ a a de viser Udvisningerne kun altfor tydeligt.

Paa Baggrund af foranstaaende Betragtninger og Redegørelser tage Udvisningerne, især som disse dreves under „Rædselsperioden“ efter Vestjyllandsturen i 1884 og atter drives under Hr. Køllers Regime i vore Dage, sig i høj Grad mærkelige ud.

Da der ved Udvisningerne tilsyneladende hverken tages Hensyn til Folkeret eller Traktater, er der efterhaanden her i Nordslesvig opstaaet en Følelse af Retløshed og Utryghed $\mathrm{i}$ disse Forhold, der ikke kan andet end øve en uheldig Indflydelse paa Folkekarakter og Folkemoral. Paa den ene Side har det avlet Trællesind og Hykleri, par den anden Side er de onde Instinkter $\mathbf{i}$ Menneskenaturen blevne levende.

Disse Udvisninger af Udlændinge og Optanter i Flæng, uden nogen som helst Begrundelse, tidt som et Lyn fra en klar Himmel, have hos ildesindede Elementer blandt de tysksindede Nordslesvigere og indvandrede (og af den Slags gives der $\mathrm{i}$ alle Samfundsklasser) vakt en Forestilling om, at her var "frit Slag“. „SyndebukPolitiken" har da ogsaa fejret sine Orgier i Folkedybet i Nordslesvig længe før Hr. Køller har knæsat den.

Hvorlunde de stakkels Optanters fortvivlede Stilling 
misbruges og udbyttes $\mathrm{i}$ rent privit personlige Forhold, ved enhver af os, og for at de uindviedes Skyld, blandt hvilke forhaabentlig ogsaa de prøjsiske Myndigheder maa regnes, vil jeg blot meddele et Par Træk, som karakteriserer Forholdene og af hvilke Historier der kunde bringes Hundreder i alle mulige Variationer - hvis de danske Optanter vare overbeviste om, at de $\mathrm{ikk}$ e ved at fortælle dem vilde kunne fremmane den Udvisningsordre, der som et Damoklessværd hænger over enhver Optants Hoved i den tyndeste Traad, prøjsisk Forvaltningskløgt har kunnet spinde:

En tysksindet Bonde fandt et Par af sine Faar døde ude paa sin Mark, tilsyneladende revne ihjel af Hunde. Han gik til en Mand (en Optant) og sagde, at det,var hans Hund der var Misdæderen. Da der ikke forelaa mindste Bevis, nægtede Optanten at betale; men den anden lod da Ytringer falde om, at han (Optanten) vel nok vidste hvem han var og hvor han hørte hen - saa betalte Optanten Faarene.

En Mand tiltvang sig uden nogen som helst Adkomst Kørsel over en Optants Mark. Denne var modig nok til at klage til Domstolene og fik Medhold. Et Par Dage efter Dommens Forkyndelse kom Optantens Børn grædende hjem fra Skole og fortaite, at den Domfældtes Børn havde sagt, at nu skulde de udvises af Landet.

Man vil forstaa, hvilken uhyggelig Tilstand af Utryghed og nervøs Ophidselse Tusinder af vore Landsmænd leve $\mathrm{i}$ under saadanne Vilkaar, og det henstilles til det tyske Folks Overvejelse, om saadanne Forhold bor taales i et civiliseret Statssamfund. 